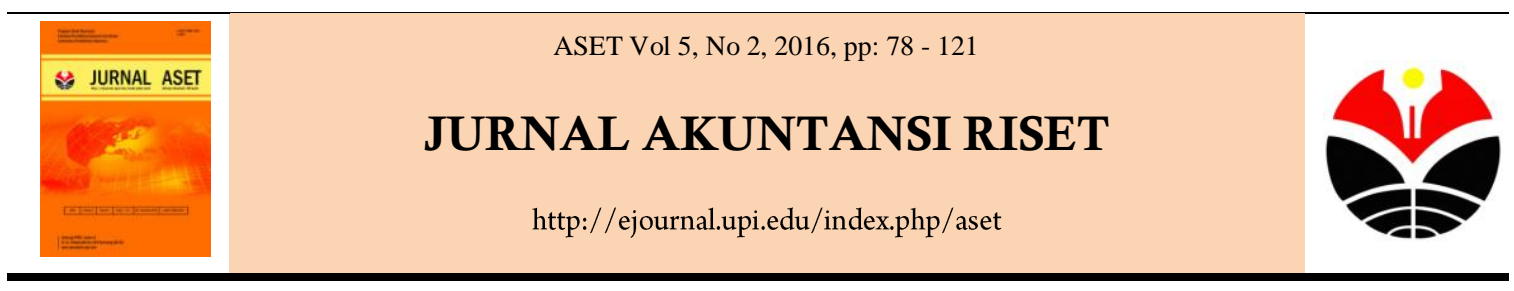

\title{
ANALISIS STRATEGI BIAYA PENGALOKASIAN BELANJA LANGSUNG PADA APBD PEMERINTAH DAERAH (PENELITIAN PADA PEMERINTAH DAERAH KOTA CIMAHI DAN KABUPATEN BANDUNG BARAT)
}

\author{
Tika Rachmatika ${ }^{1}$ \\ Universitas Pendidikan Indonesia. Bandung \\ Agus Widarsono $^{2}$ \\ Universitas Pendidikan Indonesia. Bandung
}

\section{Info Artikel Abstrak}

Diterima : 18-08-2016

Direvisi : 29-08-2016

Diterbitkan : 18-09-2016

Keywords:

Strategi Biaya; Belanja

Langsung; Pemicu Biaya
Penelitian ini bertujuan untuk mendeskripsikan penerapan strategi biaya belanja langsung dengan pendekatan analisis pemicu biaya dalam APBD pemerintah daerah se-Bandung Raya. Penelitian ini di dasarkan pada fenomena tidak seimbangnya belanja langsung dan belanja tidak langsung yang di alokasikan pada APBD. Untuk hal itu, diperlukan kajian secara mendalam mengenai penentuan input atau biaya dan diperlukan teknik analisis biaya untuk mendapatkan hasil yang sesuai. Penelitian ini menggunakan sampel pemerintah daerah se-Bandung Raya dengan dinas - dinas sebagai unit analisis. Penelitian ini menggunakan metode deskriptif pendekatan kuantitatif. Hasil penelitian menunjukkan bahwa Pemerintah Kota Cimahi rata - rata APBD tahun anggaran 2012 - 2014 menganggarkan 47\% dan Pemerintah Kab. Bandung Barat rata - rata APBD tahun anggaran 2012 - 2014 menganggarkan $41 \%$. Ditemukan beberapa strategi pengalokasian belanja langsung pada kedua pemda, diantaranya pennggunaan sistem dan aplikasi, melakukan efisiensi pegawai dan kepanitian, selain itu adalah ekstensifikasi pajak. Adapun pemicu biaya akun belanja langsung adalah belanja pegawai terdapat jumlah peraturan terbaru, jumlah kegiatan dan jumlah jam lembur sebagai pemicu biaya. Pada belanja barang dan jasa, akun sewa rumah / sewa gedung/ sewa gedung terdapat jumlah arsip, jumlah dokumen, jumlah barang dan jumlah kegiatan koordinasi sebagai pemicu biaya. Adapun pemicu biaya pada belanja jalan diantaranya adalah jumlah fasilitas transportasi

(C) Jurnal Akuntansi Riset. Program Studi Akuntansi. FPEB. UPI

\footnotetext{
Alamat korespondensi :

${ }^{1}$ Program Studi Akuntansi. FPEB. Universitas Pendidikan Indonesia E-mail (tika.rachmatika@ymail.com) (tika.rachmatika00@gmail.com)

${ }^{2}$ Program Studi Akuntansi. FPEB. Universitas Pendidikan Indonesia

E-mail (agus.widarsono@upi.edu)
}

ISSN

2541-0342(elektronik) 2086-2563 (cetak) 


\section{PENDAHULUAN}

Kebijakan desentralisasi fiskal yang telah dianut oleh Pemerintah Indonesia berdampak pada bertambahnya jumlah pekerjaan yang dimiliki oleh pemerintah daerah, salah satu diantaranya pekerjaan terkait penganggaran. Penganggaran ini bersifat desentralisasi, artinya pemerintah daerah dituntut untuk mampu memiliki kemampuan manajerial untuk memaksimalkan segala sumber daya untuk mengumpulkan sebanyak mungkin pendapatan dan mengalokasikannya ke dalam belanja pemerintahan yang proporsional. FITRA Riau (2012) menyatakan kebijakan pendapatan daerah perlu memiliki strategi belanja daerah yang tidak boros terutama pada belanja aparatur dan tidak pelit terutama pada belanja sektor strategis pengungkit pertumbuhan ekonomi dan indikator kesejahteraan masyarakat. Kebijakan pendapatan tersebut dimaksudkan agar pengelolaan anggaran daerah mampu memberikan efek positif terhadap meningkatnya pertumbuhan ekonomi, kesejahteraan dan daya saing daerah.

Warsito dkk (2011, hlm. 187) melakukan klasifikasi pengeluaran pemerintah atau belanja berdasar pada kelompok belanja terdiri dari belanja langsung dan tidak langsung. Belanja langsung didefinisikan sebagai belanja yang dianggarkan secara langsung dengan pelaksanaan program dan kegiatan. Belanja langsung terdiri dari 3 kelompok besar belanja diantaranya; (1) Belanja Pegawai; (2) Belanja Barang dan Jasa; (3) Belanja Modal. Ketiga belanja tersebut dialokasikan untuk belanja pelayanan publik. Sementara belanja tidak langsung didefinisikan sebagai belanja yang dianggarkan tidak terkait secara langsung dengan pelaksanaan program dan kegiatan. Artinya belanja tidak langsung digunakan untuk keperluan operasional dari pemerintahan daerah. Adapun kelompok belanja tidak langsung terdiri dari; (1) belanja pegawai; (2) bunga; (3) subsidi; (4) hibah; (5) bantuan sosial; (6) belanja bagi hasil; (7) bantuan keuangan; dan (8) belanja tidak terduga.

Dengan adanya dua jenis belanja yang memiliki alokasi berbeda ini, sudah seharusnya pemerintah daerah mampu menyeimbangkan atau membuat belanja tersebut memiliki proporsi yang adil dengan mengutamakan kepentingan masyarakat yang bertujuan jangka pendek dan panjang. Bahkan Menteri Dalam Negeri dalam Peraturan mengenai Pedoman Penyusunan APBD menegaskan bahwa agar lebih mengutamakan keberpihakan untuk kepentingan publik (belanja langsung) daripada kepentingan aparatur (belanja tidak langsung).

Berdasar pada publikasi statistik keuangan daerah provinsi yang dikeluarkan oleh BPS Jawa Barat, alokasi anggaran belanja langsung pada APBD dari total belanja, perbandingan realisasi belanja langsung dari total belanja, dan perbandingan realisasi belanja terhadap pendapatan. Pada penganggaran belanja langsung, Kab. Kuningan (2013) menganggarkan 29\% dan merealisasikan seluruh anggarannya, Kota Bandung menganggarkan $46 \%$ dan hanya terealisasi 43\%, Majalengka menganggarkan 35\% dan merealisasikan seluruhnya, Kab Bogor hanya menganggarkan $17 \%$ dan meningkatkan realisasi menjadi $49 \%$, kemudian Kab. Bogor (2014) meningkatkan jumlah anggarannya menjadi 50\% dan terealisasi sejumlah 47\%, Kab. Karawang merealisasikan belanja 43\%, berlanjut tahun 2014 merealisasikan 42\% dari jumlah anggaran 43\%, kemudian Kab. Bandung merealisasikan 34\% (2013) dan meningkat 37\% (2014) dari jumlah anggaran 39\%.

Kab. Kuningan (2013) memiliki total belanja 138\% dari pendapatan artinya seluruh pendapatan digunakan untuk belanja dengan kekurangan dari pendapatan 38\%, Kota Bandung 
93\%, Kab. Majalengka 96\%, Karawang (2013) membelanjakan seluruh pendapatan dengan kekurangan dari pendapatan 3\% sementara total belanja menurun menjadi 99\% (2014). Kab. Bogor memiliki kesamaan dengan Karawang, tahun 2013 101\% dan tahun 2014 menurun menjadi $91 \%$. Sementara Kab. Bandung membelanjakan $96 \%$ dan $95 \%$ pendapatan pada tahun 2013 dan 2014 secara berurutan.

Memerhatikan komposisi belanja langsung dari total belanja daerah jika dibandingkan teori komposisi berdasar Octaviani (2009) yang menyatakan komposisi harapan perbandingan belanja langsung dengan tidak langsung adalah 70 berbanding $30(70: 30)$, maka pemerintah daerah di Provinsi Jawa Barat harus melakukan evaluasi. Angka tertinggi hanya menunjukkan $49 \%$ atau masih kurang $21 \%$ dari angka harapan.

Hal ini bisa terjadi sedikitnya karena dua hal, (1) masih digunakannya incremental budgeting atau belum maksimalnya pelaksanaan performance budgeting; (2) adanya politik anggaran yang tidak pro-rakyat. Incremental budgeting menurut Mardiasmo (2009) adalah teknik penganggaran yang hanya menambah dan mengurangi nominal pada item-item anggaran yang sudah ada tahun sebelumnya sebagai dasar untuk penyesuaian anggaran tanpa melalui kajian yang dalam. Sementara dalam Permendagri nomor 13 tahun 2006 tentang pedoman pengelolaan keuangan daerah mengatur secara implisit bahwa anggaran harus berbasis kinerja (performance budget), dimana setiap program yang diajukan harus disertai dengan capaian kinerja yang diwujudkan dengan kualitas, kuantitas, efisiensi dan efektifitas pelaksanaan dari setiap program dan kegiatan. Sementara menurut Bastian (2010) kendala utama di semua negara terutama negara berkembang seperti Indonesia dalam menerapkan performance budgeting adalah dalam menetapkan pengukuran output pada sektor publik yang tidak mudah seperti pada sektor bisnis.

Untuk melakukan kajian secara mendalam penentuan input atau biaya, diperlukan teknik analisis biaya, analisis biaya berupa pengidentifikasian jenis dan perilaku biaya, perubahan biaya dan volume kegiatan. Manajemen organisasi perlu menentukan pemicu biaya (cost driver) agar dapat melakukan strategi efisiensi biaya. Berdasar pada Blocher et al (2010) cost driver adalah faktor yang mengubah jumlah biaya total, dengan kata lain, ketika pemerintah daerah mampu melakukan penganggaran dengan terlebih dahulu menganalisis dan menentukan cost driver-nya maka akan terjadi efisiensi biaya.

Berdasarkan uraian diatas dan fenomena yang terjadi, khususnya di Bandung Raya, penulis ingin mengetahui strategi dalam pengalokasian belanja langsung pada pemerintah daerah. Ketertarikan penulis terhadap strategi pengalokasian belanja langsung pada pemerintah daerah se-Bandung Raya akan dituangkan dalam skripsi berjudul:

“Analisis Strategi Biaya Pengalokasian Belanja Langsung pada APBD Pemerintah Daerah (Studi Kasus pada Pemerintah Daerah Se-Bandung Raya)”

\section{Rumusan Masalah}

Dari uraian latar belakang sebelumnya, dapat dirumuskan permasalahan yang akan diteliti yaitu bagaimana strategi biaya dengan pendekatan analisis pemicu biaya dalam pengalokasian belanja langsung APBD pemerintah daerah se- Bandung Raya. 


\section{KAJIAN LITERATUR}

\section{Belanja Daerah}

Berdasar pada Halim (2014) belanja adalah pengurangan ekuitas dana lancar pemerintah untuk pengeluaran yang ditetapkan dalam dokumen otoritas kredit anggaran (allotment) yang secara prinsip manajemen anggaran, belanja baru dibayarkan ketika barang dan jasa sudah diterima pemerintah dan belanja baru akan diakui ketika terjadinya pengeluaran dari Rekening Kas Umum Negara/Daerah.

Berdasar Warsito dkk. (2011) menyebutkan sesuai PP No. 24 tahun 2005 tentang Standar Akuntansi Pemerintahan, belanja adalah semua pengeluaran mengurangi dari rekening kas umum negara/daerah yang ekuitas dana lancar dalam periode tahun anggaran bersangkutan yang tidak akan diperoleh pembayarannya kembali oleh pemerintah.

Maka, dapat disimpulkan bahwa belanja adalah pengurangan ekuitas dana lancar pemerintah yang baru diakui dan dibayarkan ketika belanja tersebut sudah ada pada pemerintah dengan melakukan pengeluaran dari Rekening Kas Umum Negara/Daerah yang tidak akan kembali pembayarannya kepada pemerintah.

Menurut Warsito dkk. (2011) mengacu pada Permendagri No. 13 tahun 2006 tentang Pedoman Pengelolaan Keuangan Daerah, belanja daerah adalah kewajiban pemerintah daerah yang diakui sebagai pengurang nilai kekayaan bersih. Belanja daerah dipergunakan untuk pelaksanaan urusan pemerintahan yang menjadi kewenangan pemda.

Secara signifikan kegiatan pemerintah daerah terdiri dari banyak belanja, untuk menilai kewajarannya, belanja diklasifikasikan ke dalam dua kelompok, yaitu pertama belanja tidak langsung, belanja tidak langsung adalah belanja yang dianggarkan tidak terkait secara langsung dengan pelaksanaan program dan kegiatan.

Jenis- jenis belanja yang merupakan kelompok belanja tidak langsung, diantaranya; (1) Belanja pegawai. Kelompok belanja pegawai terdiri dari belanja kompensasi, dalam bentuk gaji dan tunjangan dan bentuk penghasilan lainnya kepada pegawai negeri sipil yang terdiri tunjangan pimpinan dan anggotan DPRD, kepala daerah dan wakil kepala daerah. Selain itu, pemerintah daerah berwenang memberikan tambahan penghasilan kepada pegawai negeri sipil sesuai dengan peraturan perundang-undangan dengan tujuan meningkatkan kesejahteraan dan memberikan apresiasi, adapun karakteristik dari tambahan penghasilan tersebut diantaranya: (a) Tambahan penghasilan berdasar beban kerja melebihi jam kerja normal; (b) Tambahan penghasilan berdasar tempat bertugas di daerah terpencil dengan kesulitan tinggi; (c) Tambahan penghasilan berdasar kondisi kerja dengan risiko tinggi; (d) Tambahan penghasilan berdasar kelangkaan profesi; (e) Tambahan penghasilan berdasar prestasi kerja yang tinggi dan inovasi. (2) Belanja bunga. Belanja bunga digunakan untuk pembayaran bunga utang yang dihitung atas kewajiban pokok utang. (3) Belanja subsidi. Belanja subsidi diberikan kepada perusahaan/lembaga tertentu yang memproduksi barang dan jasa yang diperlukan masyarakat agar harga jual produk/jasa tersebut dapat dijangkau oleh masyarakat banyak. (4) Belanja hibah. Belanja hibah diberikan kepada pemerintah daerah, masyarakat, perusahaan daerah, organisasi kemasyarakatan dalam bentuk uang, barang dan atau jasa. Belanja hibah bersifat bantuan yang tidak mengikat/tidak secara terus menerus dan tidak wajib serta harus sesuai dengan persyaratan yang ditetapkan dalam naskah perjanjian hibah daerah, yang berisi identitas penerima hibah, tujuan pemberian hibah dan jumlah uang yang dihibahkan. (5) Belanja bantuan sosial. Belanja bantuan sosial diberikan kepada kelompok/anggota masyarakat 
dan partai politik dalam bentuk uang, barang dan atau jasa yang ditujukan untuk bentuk kegiatan sosial kemasyarakatan. Bantuan ini diberikan secara selektif, tidak terus menerus serta memiliki kejelasan tujuan. (6) Belanja bagi hasil. Belanja bagi hasil digunakan untuk mendistribusikan pendapatan asli daerah kepada pemerintah pusat atau pemerintah daerah lainnya. (7) Bantuan keuangan. Belanja bantuan ini bertujuan untuk memberikan bantuan yang bersifat umum atau khusus dari provinsi kepada kabupaten/kota, desa atau kepada pemerintah daerah lainnya dalam rangka pemerataan atau peningkatan kemampuan keuangan. (8) Belanja tak terduga. Belanja tidak terduga ditujukan untuk belanja yang sifatnya tidak biasa seperti penanganan bencana alam atau bencana sosial lainnya yang tidak diperkirakan sebelumnya.

Kedua, belanja langsung. Belanja langsung adalah belanja yang dianggarkan terkait secara langsung dengan pelaksanaan program dan kegiatan. Kelompok belanja langsung terdiri dari; (1) belanja pegawai. Belanja pegawai dianggarkan untuk pengeluaran honorarium atau upah dalam melaksanakan program dalam kegiatan pemerintah. (2) Belanja barang dan jasa. Belanja barang dan jasa dianggarkan untuk pengeluran pembelian atau pengadaan barang yang nilai manfaatnya kurang dari satu tahun, atau penggunaan jasa dalam pelaksanaan pemerintah daerah. Belanja barang dan jasa terdiri dari; (a) belanja barang habis pakai; (b) bahan atau material; (c) jasa kantor; (d) premi asuransi; (e) perawatan kendaraan bermotor; (f) cetak atau penggandaan; (g) sewa sarana mobilitas; (h) sewa rumah/gedung/gudang/area parkir; (i) sewa alat berat; (j) sewa perlengkapan dan peralatan kantor; (k) makanan dan minuman; (1) pakaian dinas dan atribut, pakaian kerja dan pakaian khusus; (m) perjalanan dinas; (n) pemeliharaan, dll. (3) Belanja modal. Belanja modal dianggarkan untuk pengeluaran pengadaan aset tetap berwujud yang bernilai manfaat lebih dari satu tahun. Nilai dari aset tersebut adalah sejumlah harga beli di tambahkan dengan seluruh belanja yang berkaitan dengan pengadaan aset tersebut sampai bisa digunakan. Dalam hal belanja modal diatur minimal nominal dalam perpres nomor 5 tahun 2010 yang menyatakan alokasi belanja modal minimal 29\% dari total belanja daerah.

\section{Cost Strategic Tools}

Berdasar pada Anthony \& Govindarajan (2007, hlm. 56) "Strategic desrcribes the general direction in which an organization plans to move attain its goals." Maka dapat kita simpulkan bahwa strategi secara umum adalah pedoman yang digunakan organisasi dalam menjalankan perencanaannya untuk mencapai tujuan. Berdasar Blocher et al (2000) menyatakan untuk melaksanakan cost strategic terdapat beberapa alat yang bisa digunakan sesuai ciri karakteristiknya masing-masing, diantaranya sebagai berikut: (a) Benchmarking. Benchmarking merupakan proses dimana perusahaan mengidentifikasian faktor keberhasilan kritis (critical succes factor), mempelajari tentang praktik-praktik terbaik yang pernah dilakukan oleh perusahaan lain atau unit lain dan kemudian mengimplementasikan sama dengan para pesaingnya. (b) Total Quality Manajement (TQM) adalah teknik dalam mengembangkan kebijakan-kebijakan dan praktik - praktik yang dilakukan manajemen untuk meyakinkan bahwa produk dan jasa perusahaan memenuhi harapan pelanggan. (c) Contious improvement. Contious improvement adalah teknik manajemen yang dilakukan untuk meningkatkan kualitas dan keberhasilan suatu produk dengan terus menerus melakukan perbaikan. (d) Activity based costing dan Activity based management. Merupakan analisis 
yang digunakan untuk meningkatkan ketepatan dalam mengukur analisis biaya dengan memperbaiki cara penelusuran biaya terhadap objek biaya. Mengacu pada Weetman (2010: 85) bahwa terdapat 5 tahap untuk menetapkan sistem activity based costing diantaranya: (1) Mengidentifikasi aktifitas spesifik yang terjadi di perusahaan; (2) mengidentifikasi faktor yang berpengaruh terhadap biaya secara total. Atau secara umum disebut dengan cost driver; (3) Menentukan cost pool dari masing - masing aktifitas; (4) Menghitung cost driver rate dengan membagi total biaya pada cost pool dengan jumlah aktifitas yang terjadi; dan (5) mengalokasikan biaya pada produk yang diperlukan. (e) Cost Driver. Cost driver adalah faktor yang memberi dampak pada perubahan tingkat biaya total. Cost driver digunakan ketika penelusuran biaya pada pembebanan biaya secara langsung tidak dapat dilakukan.

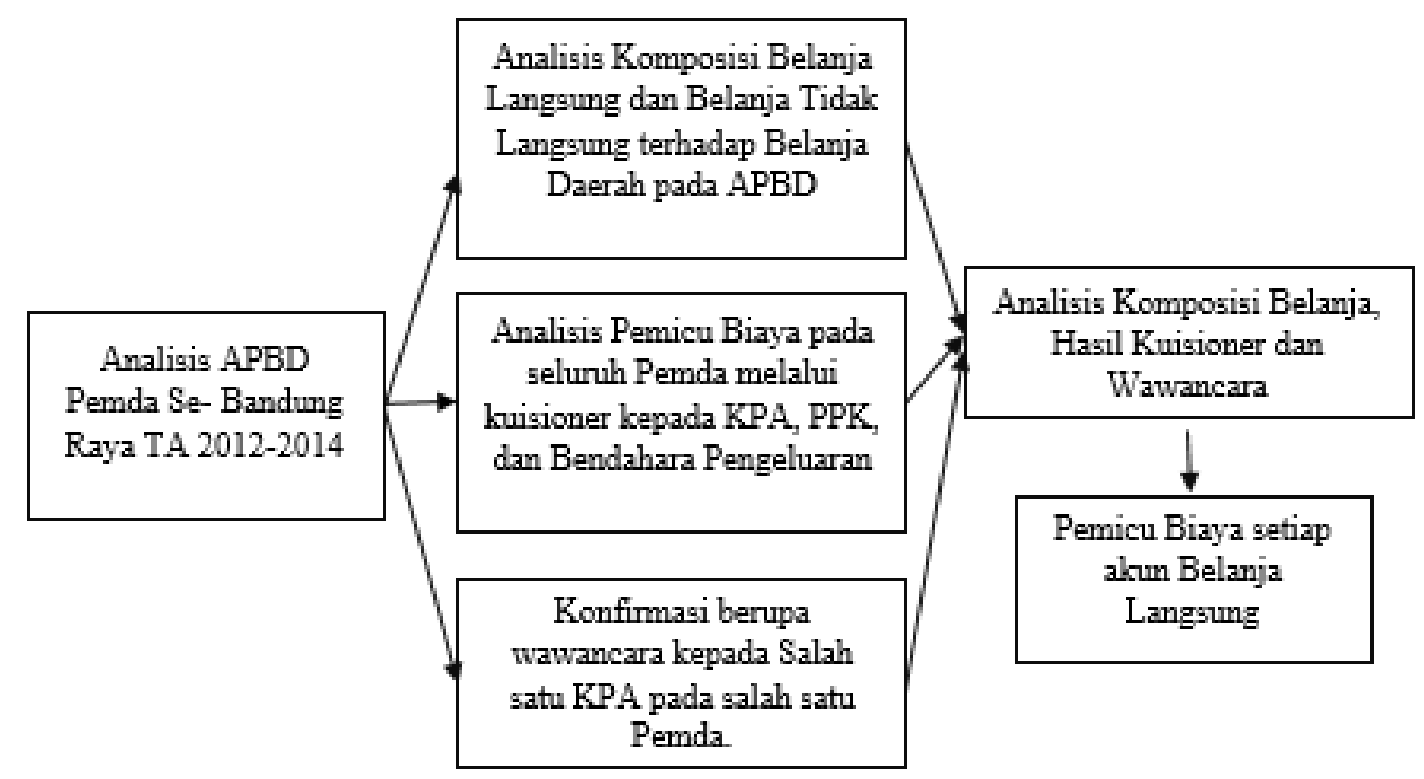

Gambar 2.1 Kerangka Pemikiran

\section{METODE PENELITIAN}

Pada penelitian ini melakukan deskripsi deskriptif dengan pendekatan kuantitatif. Menurut Sekaran (2014) studi deskriptif adalah studi yang dilakukan untuk mengetahui dan menjelaskan karakteristik variabel yang diteliti dalam suatu situasi. Selanjutnya Idrus (2009, hlm. 29) menjelaskan metode penelitian kuantitatif adalah metode yang meyakini bahwa hukum - hukum tersebut dapat ditemukan dari data empiris dan menggunakan sampel yang dapat digunakan untuk melakukan generalisasi secara umum.

\section{Operasionalisasi Variabel}

Berdasar Anthony \& Govindarajan (2007, hlm. 56) "Strategic desrcribes the general direction in which an organization plans to move attain its goals." Dapat simpulkan bahwa strategi biaya adalah strategi yang digunakan organisasi atau instansi dalam mencapai tujuan. Dalam penelitian ini terdiri dari tiga subvariabel, diantaranya :

a) Subvariabel Input.

Diukur dengan analisis rata- rata APBD se- Bandung Raya. Dihitung dengan membandingkan total APBD dengan jumlah tahun analisis: 
Total APBD 3 Tahun (2012-2014)

3

b) Subvariabel Proses.

Diukur dengan komposisi belanja langsung terhadap belanja tidak langsung. Dihitung dengan membandingkan komposisi belanja langsung terhadap belanja daerah.

\section{Total Belanja Langsung}

Total Belanja Daerah

c) Subvariabel Output.

Subvariabel output diukur dengan menanyakan dalam kuisioner mengenai pemicu biaya dari beberapa akun belanja langsung, diantaranya:

- Belanja pegawai;

- Sewa rumah / gedung / gudang / area parkir;

- Sewa alat berat;

- Pakaian khusus;

- Belanja tanah;

- Belanja gedung;

- Belanja jalan;

- Taman dan hutan kota;

- Buku / Perpustakaan; dan

- Hewan ternak.

\section{Unit Analisis}

Populasi dalam penelitian ini adalah Anggaran dan Pendapatan Belanja Daerah Pemerintah Daerah se-Bandung Raya. Berikut daftar pemerintah daerah yang berada di Bandung Raya. Teknik sampling yang digunakan dalam penelitian ini adalah nonprobability sampling atau penyampelan tak berpeluang dengan pendekatan sampling purposive. Penyampelan tak berpeluang adalah teknik yang tidak melaksanakan perandoman, sehingga peluang setiap subjek dalam populasi untuk terpilih sebagai sampel tidak diketahui (Ali, 2014, hlm. 119). Sedangkan penyampelan purposif adalah teknik penggunaan sampel yang didasarkan pada pertimbangan peneliti sesuai dengan tujuan penelitian itu. Sampel dalam penelitian ini adalah APBD milik Pemda se-Bandung Raya yang memiliki anggaran rata - rata ter-rendah dalam kurun waktu 2012-2014 dari masing - masing karakter kabupaten dan kota. Adapun tahun analisis yang akan digunakan adalah tiga tahun anggaran, yaitu tahun anggaran 2012-2014. Maka Pemda yang menjadi sampel dalam penelitian ini adalah Kabupaten Bandung Barat mewakili unsur kabupaten dan Kota Cimahi mewakili unsur kota.

\section{Teknik Pengumpulan Data}

Dalam penelitian ini penulis menggunakan data sekunder dan data primer yang berkaitan dengan masalah penelitian. Data yang digunakan dalam penelitian ini adalah laporan realisasi anggaran dan pendapatan belanja daerah se-Bandung Raya tahun 2012-2014. Sumber data sekunder diambil dari laporan statisitik keuangan daerah BPS Jawa Barat, digunakan untuk menganalisis pemerintah dengan anggaran rata - rata ter-rendah. Selanjutnya digunakan data primer berupa kuisioner disebarkan kepada 3 responden diantaranya Kuasa Pengguna 
Anggaran (Kepala Dinas) , Pejabat Pengelola Keuangan (Kasubag Keuangan) dan Bendahara Pengeluaran dari setiap Dinas pada kedua Pemda terpilih. Data primer berikutnya diambil dengan wawancara kepada salah satu KPA pada salah satu pemda dilakukan untuk melakukan konfirmasi hasil analisis dan kuisioner.

\section{Teknik Analisis Data}

Untuk menganalisis data penelitian yang dikumpulkan peneliti dalam rangka menjawab rumusan masalah, peneliti melakukan langkah sebagai berikut :

a) Mengumpulkan laporan realisasi anggaran pendapatan dan belanja daerah pemerintah daerah se-Bandung Raya tahun anggaran 2012-2014.

b) Melakukan analisis komposisi penganggaran belanja langsung.

i. Analisis dilakukan dengan membandingkan komposisi belanja langsung setiap pemerintah daerah terhadap total anggaran belanja.

ii. Analisis komposisi belanja langsung $=\frac{\text { Total Belanja Langsung }}{\text { Total Belanja Daerah }}$

c) Melakukan analisis dengan menggunakan statistika deskriptif rata -rata, max dan min.

d) Melakukan penyebaran kuisioner kepada seluruh dinas pada kedua Pemerintah daerah terpilih. Instrumen kuisioner terlampir.

e) Melakukan analisis dengan menggunakan statistika deskriptif max, min dan rata-rata.

Analisis dengan menggunakan statistik deskriptif ini dilakukan untuk mendeskripsikan hasil analisis komposisi belanja langsung yang telah dilakukan sebelumnya dan hasil kuisioner yang telah disebarkan. Statistik deskriptif yang digunakan adalah menghitung rata-rata. Rata-rata hitung atau mean menurut Ali (2014, hlm. 454) yaitu bilangan yang mewakili nilai dari bilangan-bilangan lain pada distribusi. Selain itu digunakan statistika maksimun dan minimum untuk mendeskripsikan jumlah maksimun dan minimum yang dianggarkan.

f) Melakukan pengumpulan data melalaui wawancara mendalam kepada salah satu KPA pada salah satu pemerintah daerah terpilih.

g) Melakukan penarikan kesimpulan pada hasil analisis komposisi belanja langsung, kuisioner dan wawancara.

h) Mendeskripsikan pemicu biaya setiap belanja langsung. 
HASIL DAN PEMBAHASAN

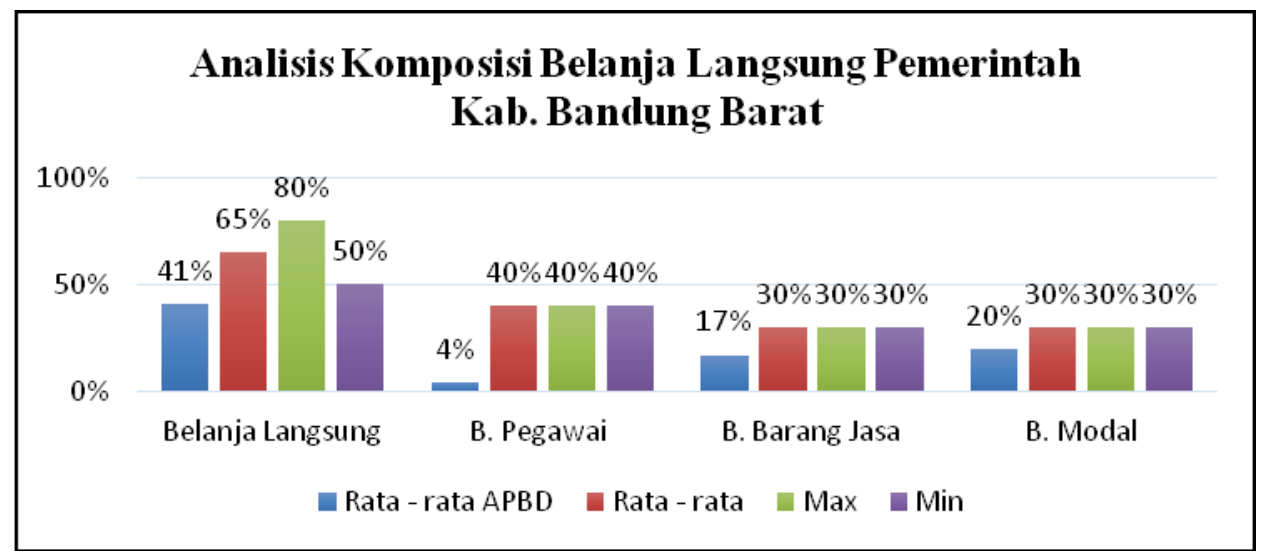

Analisis Komposisi Belanja Langsung Pemerintah Kota Cimahi

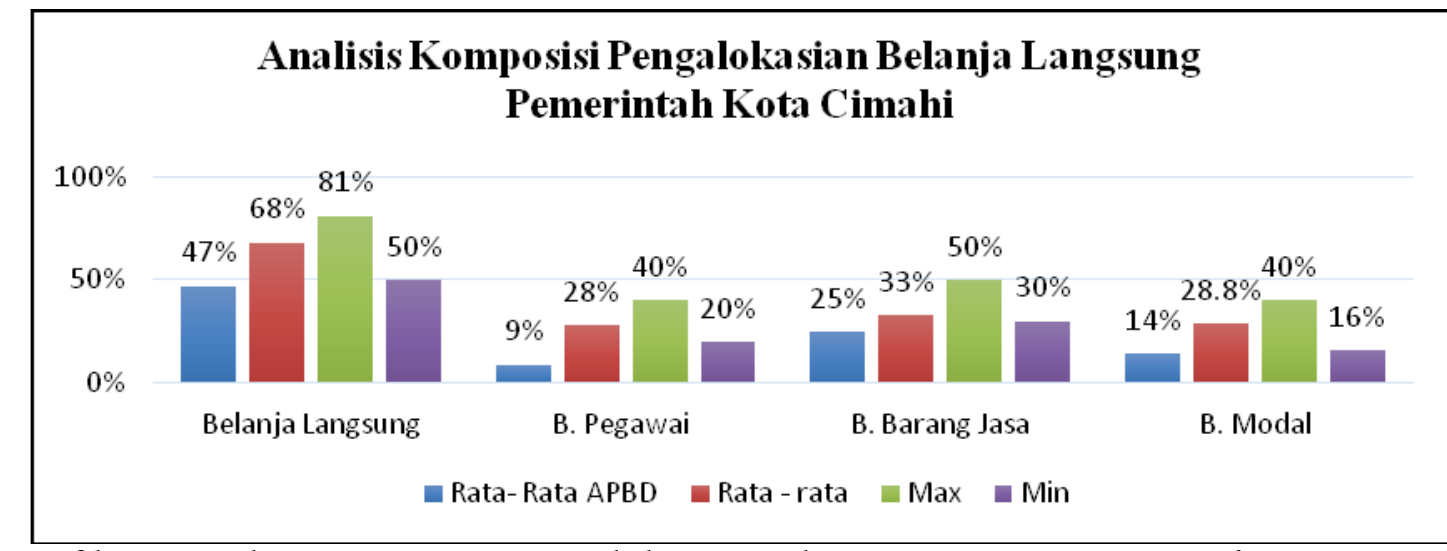

Grafik 1.1 Analisis Komposisi Pengalokasian Belanja Langsung Pemerintah Kota Cimahi Sumber: Data diolah.

Berdasar grafik 1.1, dapat kita perhatikan bahwa dalam APBD Pemerintah Kota Cimahi secara rata - rata dalam kurun waktu 3 tahun anggaran hanya menganggarkan 47\%, namun hasil sebaran kuisioner secara rata - rata menyebutkan komposisi belanja langsung di anggarkan 68\%. Responden lain menyatakan bahwa belanja langsung di anggarkan $81 \%$ dari total belanja daerah dan minimal 50\%. Selanjutnya dalam pengalokasian belanja pegawai, APBD Pemerintah Kota Cimahi hanya menganggarkan rata 9\%, sementara hasil kuisioner menyatakan bahwa belanja pegawai dianggarkan $20 \%$. Responden lain mengharapkan minimal belanja pegawai dapat dianggarkan $20 \%$ dan maksimal $40 \%$. Pada belanja barang dan jasa masih terjadi kesenjangan antara APBD dan fakta lapangan, diantaranya APBD menganggarkan 25\% namun hasil kuisioner menyatakan bahwa belanja barang jasa diharapkan dianggarkan 33\% dari belanja daerah. Begitupun dengan belanja modal, APBD hanya menganggarkan $14 \%$ sementara hasil kuisioner menyatakan harapan agar belanja modal dapat dianggarkan sejumlah 28,8\% dari total belanja daerah.

Analisis Komposisi Belanja Langsung Pemerintah Kab. Bandung Barat

Grafik 1.2 Analisis Komposisi Pengalokasian Belanja Langsung Pem. Kab. Bandung Barat 


\section{Sumber: Data diolah.}

Berdasar grafik 1.2, dapat kita perhatikan bahwa dalam APBD Pemerintah Kab. Bandung Barat secara rata - rata dalam kurun waktu 3 tahun anggaran hanya menganggarkan $41 \%$, namun hasil sebaran kuisioner secara rata - rata menyebutkan komposisi belanja langsung di anggarkan 65\%. Responden lain menyatakan bahwa belanja langsung di anggarkan $80 \%$ dari total belanja daerah dan minimal 50\%. Selanjutnya dalam pengalokasian belanja pegawai, APBD Pemerintah Kota Cimahi hanya menganggarkan rata 4\%, sementara hasil kuisioner menyatakan bahwa belanja pegawai dianggarkan $40 \%$. Pada belanja barang dan jasa masih terjadi kesenjangan antara APBD dan fakta lapangan, diantaranya APBD menganggarkan $17 \%$ namun hasil kuisioner menyatakan bahwa belanja barang jasa diharapkan dianggarkan 30\% dari belanja daerah. Begitupun dengan belanja modal, APBD hanya menganggarkan 20\% sementara hasil kuisioner menyatakan harapan agar belanja modal dapat dianggarkan sejumlah $30 \%$ dari total belanja daerah.

Mengacu pada perbandingan fakta data APBD dengan hasil sebaran kuisioner, secara jelas kita dapat melihat adanya senjangan antara harapan yang berdasar pada regulasi dan atau kebutuhan di lapangan. Maka peneliti melakukan konfirmasi kepada Sekertaris Dinas Pendapatan Kota Cimahi yang secara fungsi memiliki peran dalam penganggaran mengenai pengalokasian belanja langsung, diantaranya mengenai penyebab masih sulitnya belanja langsung dianggarkan lebih besar daripada belanja tidak langsung adalah adanya pemerintah daerah yang memiliki jumlah pegawai banyak dan belum mampu memaksimalkan penggunaan sistem serta aplikasi dapat dipastikan akan selalu meminimalisir belanja langsung dikarenakan sumber pendanaan utama pemerintah daerah masih mengandalkan dana perimbangan pemerintah pusat.

\section{Analisis Pemicu Biaya Pemerintah Kota Cimahi}

Berdasar hasil kuisioner yang peneliti terima kembali, mengenai analisis pemicu biaya, dapat di deskripsikan bahwa pemicu biaya pengalokasian belanja langsung pada Pemerintah Kota Cimahi adalah sebagai berikut;

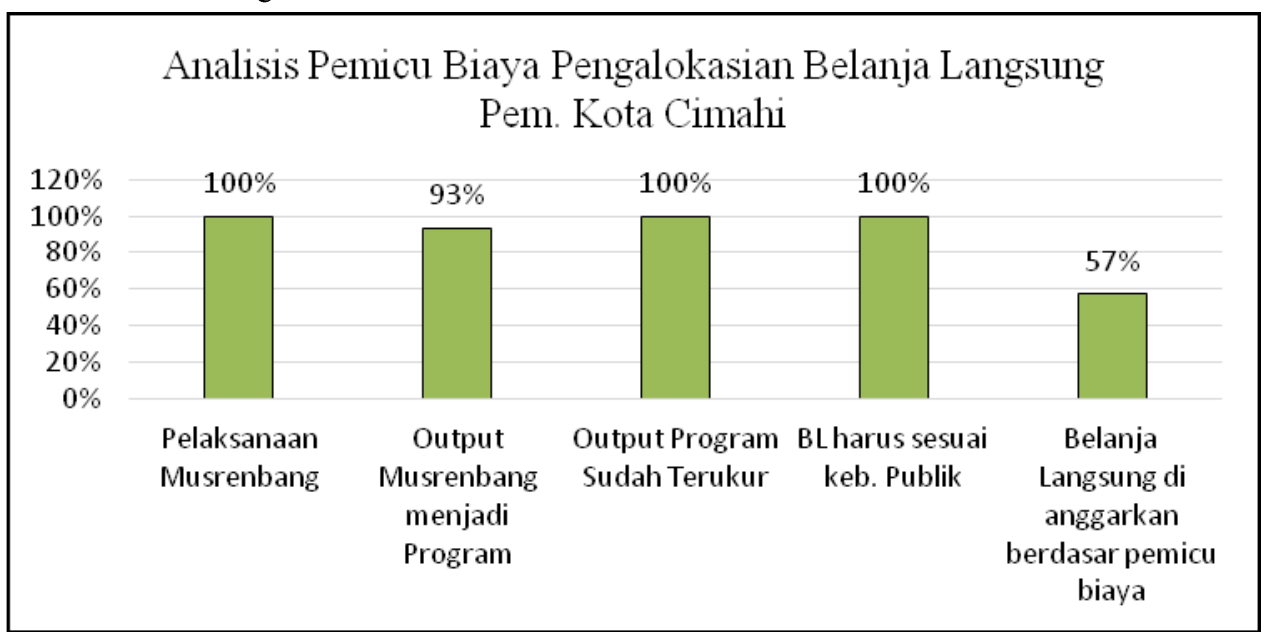

Grafik 1.3 Analisis Pemicu Biaya Pengalokasian Belanja Langsung Pem. Kota Cimahi Sumber: Data diolah.

Grafik 1.3 mendeskripsikan bahwa musrenbang selalu dilaksanakan sebelum di terbitkan kebijakan umum anggaran (KUA) dan prioritas dan plafon anggaran sementara 
(PPAS) untuk mengumpulkan aspirasi terkait dengan pembangunan daerah. Dan 93\% responden menyatakan program hasil musrenbang selalu di kukuhkan menjadi program atau kegiatan yang dianggarkan satu tahun anggaran atau tahun berikutnya adapun beberapa responden menyatakan tidak semua output di kukuhkan menjadi program dalam satu tahun anggaran, hal ini karena memerhatikan kekuatan anggaran dan prioritas rencana kerja kota, sehingga hasil dari musrenbang akan di susun skala prioritas.

Berikutnya, 100\% diantaranya menyatakan bahwa setiap program yang dianggarakan sudah di tentukan dan diukur terlebih dahulu output-nya. Karena setiap program harus dipastikan bisa bermanfaat bagi masyarakat. Sejalan dengan ini, 100\% responden diantaranya menyatakan bahwa belanja langsung harus dianggarkan sesuai kebutuhan publik. Namun 57\% diantaranya menyatakan belanja langsung dianggarkan berdasar pada masing - masing pemicu biaya-nya, hal ini berarti dalam pengalokasian belanja langsung dalam APBD masih terdapat faktor lain.

\section{Analisis Pemicu Biaya Kabupaten Bandung Barat}

Berdasar hasil kuisioner yang peneliti terima kembali, mengenai analisis pemicu biaya, dapat di deskripsikan bahwa pemicu biaya pengalokasian belanja langsung pada Pemerintah

Kab. Bandung Barat adalah sebagai berikut;

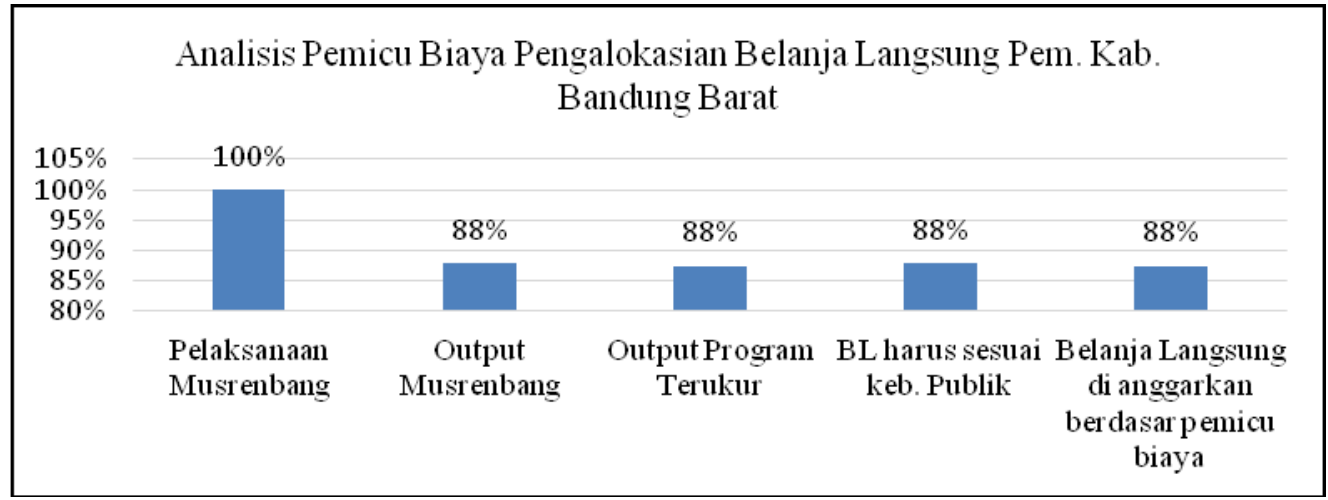

Grafik 1.4 Analisis Pemicu Biaya Pengalokasian Belanja Langsung Pem. Kab. Bandung

Barat

\section{Sumber: Data di olah}

Grafik 1.4 mendeskripsikan bahwa musrenbang selalu dilaksanakan sebelum di terbitkan kebijakan umum anggaran (KUA) dan prioritas dan plafon anggaran sementara (PPAS) untuk mengumpulkan aspirasi terkait dengan pembangunan daerah. Namun $88 \%$ responden menyatakan program hasil musrenbang selalu di kukuhkan menjadi program atau kegiatan yang dianggarkan satu tahun anggaran atau tahun berikutnya, hal ini mengacu pada skala prioritas, pun tidak pada tahun yang sama akan di alokasikan pada tahun anggaran berikutnya. Selain itu bergantung pada area atau lokasi usulan yang disampaikan.

Berikutnya $88 \%$ diantaranya menyatakan bahwa setiap program yang dianggarakan sudah di tentukan dan diukur terlebih dahulu output-nya. Karena setiap program harus dipastikan bisa bermanfaat bagi masyarakat. Sejalan dengan ini, $88 \%$ diantaranya menyatakan bahwa belanja langsung harus dianggarkan sesuai kebutuhan publik dan belanja langsung dianggarkan berdasar pada masing - masing pemicu biaya-nya. Hal ini menjelaskan bahwa pengalokasian belanja langsung dalam APBD sudah menjadi salah satu prioritas. 


\section{Pemicu Biaya Pengalokasian Belanja Langsung Pemerintah Kota Cimahi dan Kab. Bandung Barat}

Berdasar pada hasil kuisioner yang kembali, di peroleh pemicu biaya dari beberapa akun belanja langsung pada kedua pemerintah daerah. Atas hasil kuisioner yang terkumpul, peneliti melakukan konfirmasi kepada Kasubag Keuangan Dinas Pendapatan Kota Cimahi periode 2009 - 2015 terkait berbagai macam pemicu biaya dalam satu akun yang dialokasikan. Berikut daftar pemicu biaya pengalokasian belanja langsung dari kedua pemda tersebut;

Tabel 1.1

Pemicu Biaya Pengalokasian Belanja Langsung Pemerintah Daerah Se- Bandung Raya

\begin{tabular}{|c|c|}
\hline Jenis Belanja & Pemicu Biaya \\
\hline Belanja Pegawai & $\begin{array}{l}\text { - jumlah peraturan terbaru, } \\
\text { - jumlah kegiatan, dan } \\
\text { - jumlah jam lembur }\end{array}$ \\
\hline \multicolumn{2}{|l|}{$\begin{array}{c}\text { Belanja Barang dan } \\
\text { Jasa }\end{array}$} \\
\hline $\begin{array}{l}\text { 1. Sewa Rumah / } \\
\text { Sewa gedung / } \\
\text { Sewa Gudang }\end{array}$ & $\begin{array}{l}\text { - jumlah arsip, } \\
\text { - jumlah dokumen, } \\
\text { - jumlah barang, dan } \\
\text { - jumlah kegiatan koordinasi }\end{array}$ \\
\hline 2. Alat Berat & - jumlah proyek \\
\hline 3. Pakaian Khusus & - jumlah penyesuaian kondisi lapangan \\
\hline \multicolumn{2}{|l|}{ Belanja Modal } \\
\hline 1. Tanah & $\begin{array}{l}\text { - jumlah kebutuhan lahan khusus, } \\
\text { - jumlah keperluan ruang, dan } \\
\text { - jumlah sarana yang di perlukan. }\end{array}$ \\
\hline 2. Gedung & $\begin{array}{l}\text { - jumlah sarana prasarana yang di } \\
\text { perlukan, dan } \\
\text { - jumlah gedung yang perlu di rehab. }\end{array}$ \\
\hline 3. Jalan & $\begin{array}{l}\text { - jumlah fasilitas transportasi, } \\
\text { - jumlah keperluan akses jalan baru, dan } \\
\text { - jumlah peningkatan kualitas jalan }\end{array}$ \\
\hline 4. Taman dan Hutan & $\begin{array}{l}\text { - ketentuan ruang terbuka hijau, } \\
\text { - keperluan kualitas udara, dan } \\
\text { - jumlah daerah serapan air }\end{array}$ \\
\hline $\begin{array}{l}\text { 5. Buku / } \\
\text { Perpustakaan }\end{array}$ & $\begin{array}{l}\text { - jumlah permintaan jumlah buku, } \\
\text { - jumlah peminjam, } \\
\text { - jumlah siswa yang mengacu pada standar } \\
\text { pelayanan minimal. }\end{array}$ \\
\hline 6. Hewan Ternak & - jumlah kelompok pengembang. \\
\hline
\end{tabular}

Sumber: Data di olah. 


\section{SIMPULAN DAN SARAN}

\section{Simpulan}

Berdasarkan hasil analisis yang telah dijelaskan sebelumnya, maka dapat ditarik kesimpulan yang berkaitan dengan penelitian mengenai analisis strategi pengalokasian belanja langsung pada APBD pemerintah daerah (penelitian pada Pemerintah Daerah Kota Cimahi dan Kab. Bandung Barat) adalah:

1. Strategi pengalokasian belanja langsung strategi pengalokasian belanja langsung yang digunakan adalah salah satunya dengan melakukan efisiensi pegawai, dalam hal ini adalah adanya penawaran pensiun dini kepada pegawai yang dianggap produktivitasnya sudah menurun. Strategi efisiensi biaya berikutnya adalah dengan cara merampingkan struktur kepanitiaan. Strategi terakhir yang digunakan adalah dengan melakukan ekstensifikasi pendapatan daerah.

2. Dalam pengalokasian belanja langsung terdapat kesamaan atau kesepakatan diantara kedua pemda tersebut bahwa belanja langsung di alokasian minimal $50 \%$ (lima puluh persen).

3. Pemicu biaya akun belanja langsung pada pemerintah daerah se-bandung raya berdasar sampel terpilih adalah

a. Belanja pegawai terdapat jumlah peraturan terbaru, jumlah kegiatan dan jumlah jam lembur sebagai pemicu biaya.

b. Belanja barang dan jasa, akun sewa rumah / sewa gedung/ sewa gedung terdapat jumlah arsip, jumlah dokumen, jumlah barang dan jumlah kegiatan koordinasi sebagai pemicu biaya. Pada akun alat berat yang menjadi pemicu biaya adalah jumlah proyek. Sementara pada akun pakaian khusus yang menjadi pemicu biaya adalah jumlah penyesuaian kondisi lapangan.

c. Sementara pada belanja modal, diantaranya ; Belanja tanah jumlah kebutuhan lahan khusus, jumlah keperluan ruang dan jumlah sarana yang diperlukan dijadikan sebagai pemicu biaya. Sementara pada belanja gedung, jumlah sarana prasarana yang diperlukan dan jumlah gedung yang perlu di rehab dijadikan pemicu biaya. Adapun pemicu biaya pada belanja jalan diantaranya adalah jumlah fasilitas transportasi, jumlah keperluan akses jalan baru dan jumlah peningkatan kualitas jalan. Selain itu, pada belanja taman dan hutan, ketentuan ruang terbuka hijau, keperluan kualitas udara dan jumlah daerah serapan air dijadikan sebagai pemicu biaya. Sementara pada akun buku/ perpustakaan pemicu biaya pada akun tersebut adalah jumlah permintaan jumlah buku, jumlah peminjam, dan jumlah siswa yang mengacu pada standar pelayanan minimal. Pada akun hewan ternak, jumlah kelompok pengembang dijadikan sebagai pemicu biaya.

Saran

Berdasarkan hasil penelitian yang telah diperoleh, penulis dapat mengemukakan beberapa saran sebagai berikut:

1. Diharapkan agar pemerintah daerah mengalokasikan belanja langsung berdasarkan pemicu biaya masing - masing akun dan menjadikan output sebagai tujuan utama, 
sehingga ini bisa dijadikan sebagai salah satu strategi dalam pengalokasian belanja langsung.

2. Dalam pengalokasian belanja langsung sebaiknya pemerintah daerah mengalokasikan minimal 50\% dari total belanja daerah atau tetap menjadikan belanja langsung menjadi prioritas.

3. Penelitian ini dirancang dengan analisis deskriptif melalui pendekatan kuantitatif. Untuk peneliti selanjutnya, sebaiknya dirancang penelitian dengan pendekatan kualitatif . Agar pengamatan dan analisis bisa dilakukan lebih mendalam. Selain itu peneliti selanjutnya lebih baik fokus pada satu pemerintah daerah saja dengan unit analisis Badan Pengawas Daerah dan dilakukan pada saat periode penganggaran sehingga peneliti dapat terjun langsung pada masa asistensi BAPEDA terhadap SKPD.

\section{DAFTAR PUSTAKA}

Ali, M. (2014). Memahami Riset Pelaku dan Sosial. Bandung: Bumi Aksara.

Anthony, R. N., Govindarajan V. (2007). Management Control Systems. New York : McGraw Hill.

Blocher et al. (2000). Manajemen Biaya. Jakarta. Salemba Empat

Mihut, Tomai. A Cost Model for the IT Department. Journal of Applied Quantitave Methods Vol. 5 No. 2 Summer 2010 pg. 358 - 364.

Sekaran, U. (2014). Research Methods for Business. Buku 1. Edisi 4. Jakarta: Salemba Empat. Warsito dkk. (2011). Akuntansi Sektor Publik. Pendekatan Penganggaran Daerah dan Akuntansi Keuangan Daerah.Buku 1. Semarang: Badan Penerbit UNDIP dan Widya Karya

Weetman, P. (2010). Management accounting. Second edition. England: Pearson Education Limited. 